\title{
Raised hepatic free fatty acids in a patient with acute fatty liver after gastric surgery for morbid obesity
}

\author{
SR CAIRNS, AE KARK, TJ PETERS \\ From the Divisions of Clinical Cell Biology and Clinical Sciences, Medical Research Council Clinical Research \\ Centre, Harrow, Middlesex
}

SUMMARY A patient died after gastric surgery for morbid obesity. Necropsy showed severe fatty liver, and biochemical analysis of hepatic lipids showed unusually high free fatty acid concentrations, which may have contributed to the hepatic failure.

A 33 year old caucasian man weighing $146 \mathrm{~kg}$ was admitted to Northwick Park Hospital for a gastric reduction operation for morbid obesity. He was not diabetic, was taking no drugs, and was not an alcohol abuser. Preoperative investigation showed normal haematology, urea and electrolytes, glucose, and liver function tests. Serum cholesterol and triglyceride concentrations were normal.

A gastric bypass operation was uncomplicated, but within 12 hours the patient developed fever, tachycardia, hypotension, and oliguria. Blood cultures were sterile, and there was no leucocytosis. The serum transaminase activity had increased to $235 \mathrm{IU} / 1$ (normal range <35) and rose further to $561 \mathrm{IU} / 1$ shortly before death. Serum alkaline phosphatase activity remained within normal limits, and serum bilirubin was minimally increased at $19 \mu \mathrm{mol} / 1$ (normal range < 17). Serum albumin concentration fell to $24 \mathrm{~g} / \mathrm{l}$.

Despite broad spectrum antibiotics, assisted ventilation, and inotropes the patient remained hypotensive and uraemic with progressive deterioration. The abdomen remained soft, and diagnostic peritoneal tapping showed no fluid or pus. Three hours before death electrocardiogram changes occurred suggesting an acute anteroseptal myocardial infarction. The patient died following a cardiac arrest six days postoperatively.

Liver biopsy was performed immediately and a portion placed in $0.15 \mathrm{~mol} / \mathrm{l}$ sodium chloride and stored at $-20^{\circ} \mathrm{C}$ for biochemical analysis. The remainder was processed for light microscopy, which showed severe fatty liver with the fat forming large cysts but also small vacuoles within hepatocytes. In addition, there was extensive periportal inflammation (Figure). Hepatic lipids, protein, and DNA were assayed, as described by Cairns and Peters. ${ }^{1-3}$

Accepted for publication 30 January 1986

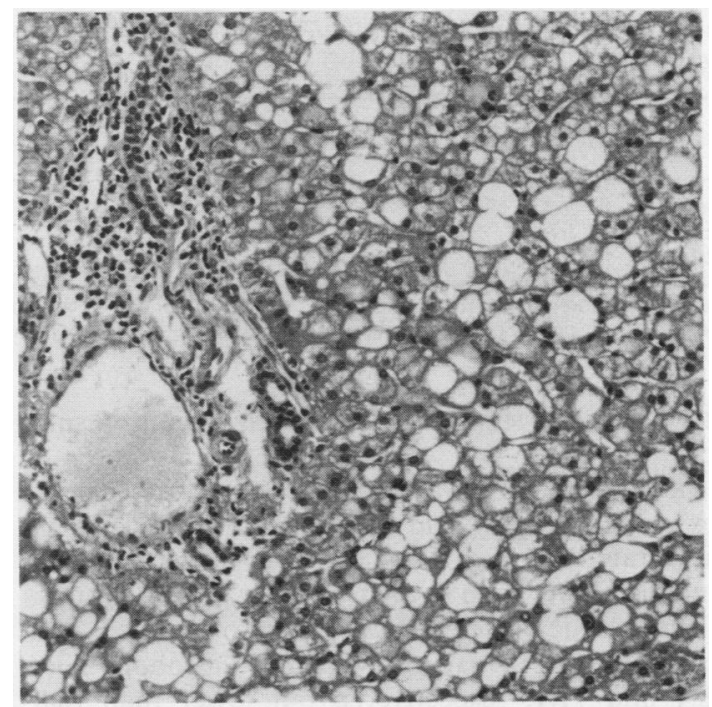

Histological section of liver biopsy specimen. $\times 180$.

HEPATIC LIVER ANA L YSIS

Table 1 shows the hepatic lipid content of the patient compared with that of normal controls and patients with alcoholic fatty liver. The patient had a grossly raised total hepatic lipid concentration, principally due to an increase in triglyceride. Esterified cholesterol was also increased, the free fatty acid concentration was twice that of the other patient groups. Proportions of individual free fatty acids were assayed by gas-liquid chromatography (Table 2$).{ }^{1}$ The proportions of palmitoleic (16:1), oleic (18:1), and linoleic (18:2) acid were increased and palmitate $(16: 0)$, stearate (18:0), and linolenate (18:3) decreased. Proportions of hepatic phospholipid and triglyceride 
Table 1 Lipid analysis of liver biopsy specimens from patient, alcoholics, ${ }^{4}$ and control subjects ${ }^{4}$

\begin{tabular}{|c|c|c|c|c|c|c|}
\hline & $\begin{array}{l}\text { Free } \\
\text { cholesterol }\end{array}$ & $\begin{array}{l}\text { Esterified } \\
\text { cholesterol }\end{array}$ & Phospholipid & $\begin{array}{l}\text { Free } \\
\text { fatty acid }\end{array}$ & Triglyceride & $\begin{array}{l}\text { Total } \\
\text { lipid }\end{array}$ \\
\hline $\begin{array}{l}\text { Controls }(n=7) \\
\text { Alcoholic fatty liver }(n=10) \\
\text { Patient }\end{array}$ & $\begin{array}{l}3.0(0 \cdot 6) \\
5 \cdot 8(1.4) \\
4 \cdot 8\end{array}$ & $\begin{array}{l}0.4(0 \cdot 1) \\
1.4(0 \cdot 3) \\
1.5\end{array}$ & $\begin{array}{l}23.5(3 \cdot 6) \\
30.8(5 \cdot 7) \\
21.9\end{array}$ & $\begin{array}{l}8.7(0.8) \\
8.6(1.8) \\
16.1\end{array}$ & $\begin{array}{c}8.9(2 \cdot 0) \\
96 \cdot 5(22 \cdot 5) \\
146\end{array}$ & $\begin{array}{l}44.5(5.9) \\
14.5(4 \cdot 0) \\
190\end{array}$ \\
\hline
\end{tabular}

Lipid expressed as $\mu \mathrm{mol} / \mathrm{mg}$ DNA (SE).

Table 2 Tissue free fatty acid composition in control subjects, ${ }^{4}$ patients with alcoholic fatty liver ${ }^{4}$ and patient with acute fatty liver

\begin{tabular}{|c|c|c|c|c|c|c|c|}
\hline & \multicolumn{7}{|c|}{ Distribution of free fatty acids (\%) } \\
\hline $\begin{array}{l}\text { Controls }(n=9) \\
\text { Alcoholic fatty liver }(n=10) \\
\text { Patient }\end{array}$ & $\begin{array}{l}16: 0 \\
56 \cdot 3(3 \cdot 4) \\
54 \cdot 3(3 \cdot 6) \\
34\end{array}$ & $\begin{array}{l}16: 1 \\
0.9(0.6) \\
1.3(0.5) \\
15\end{array}$ & $\begin{array}{l}18: 0 \\
13 \cdot 6(1 \cdot 8) \\
13 \cdot 7(1 \cdot 7) \\
6\end{array}$ & $\begin{array}{l}18: 1 \\
16.6(3.4) \\
17.0(2 \cdot 8) \\
25\end{array}$ & $\begin{array}{l}18: 2 \\
5 \cdot 6(2 \cdot 3) \\
4 \cdot 5(1 \cdot 4) \\
15\end{array}$ & $\begin{array}{l}18: 3 \\
<1 \cdot 0 \\
2.9(0.9) \\
<1 \cdot 0\end{array}$ & $\begin{array}{l}20: 4 \\
<1 \cdot 0 \\
4 \cdot 0(0 \cdot 9) \\
5\end{array}$ \\
\hline
\end{tabular}

Table 3 Double bond index:saturated fatty acid ratio and saturated:unsaturated fatty acid ratio of free fatty acids in human livers

\begin{tabular}{lllc}
\hline & $\begin{array}{l}\text { Double bond index: } \\
\text { saturated fatty acid }\end{array}$ & $\begin{array}{l}\text { Saturated: } \\
\text { unsaturated fatty acid }\end{array}$ & $\begin{array}{l}\text { Non-essential: } \\
\text { essential fatty acids }\end{array}$ \\
\hline Controls & 0.41 & 3.0 & 15.6 \\
Alcoholic fatty liver & 0.76 & 2.3 & 7.6 \\
Patient & 2.25 & 0.67 & 4.0 \\
\hline
\end{tabular}

The double bond index:saturated fatty acid ratio is calculated by dividing the sum of the percentage proportions of individual unsaturated fatty acids, each multiplied by the number of double bonds in the fatty acid, by the percentage of saturated fatty acid.

fatty acids were similar to those found in control subjects.

Table 3 shows the various indices for fatty acid ratios in the free fatty acid fraction. The proportion of unsaturated fatty acids was higher in the patient with acute fatty liver than in the two other patient groups.

The hepatic protein:DNA ratio in our patient was similar to that of patients with fatty alcoholic liver (68:1 and 71:1, respectively), but lower than that found in control subjects (103:1).

\section{Discussion}

Our patient was grossly obese but was otherwise fit and active before gastric surgery. He was a security guard. There were no peroperative problems, but within a few hours he had developed fever, tachycardia, and hypotension. There was no clear cause for multiorgan failure, and he died despite full supportive care. Full necropsy showed no sign of infection or gastric leakage. The only remarkable finding was severe fatty liver with extensive periportal inflammation (Figure), a complication not previously reported after this operation. Biochemical analysis of hepatic lipids showed that not only were triglyceride and esterified cholesterol concentrations increased, as in other forms of fatty liver, ${ }^{4}$ but there was also an $\overrightarrow{\vec{P}}$ unusually high concentration of free fatty acids.

Free fatty acids are highly reactive; they damage $\supset$ biological membranes ${ }^{5-7}$ and are thus potentially cytotoxic. They are also amphipathic and act as potent detergents. Raised values of hepatic free fatty acids? have also been found in a necropsy specimen from a $\frac{5}{3}$ patient who died in hepatic failure due to fatty liver of pregnancy ${ }^{8}$ and also in patients with alcoholic hepatitis and morbid obesity. ${ }^{9}$ It has therefore been suggested that free fatty acids are responsible for liver damage in these conditions.

Tissue free fatty acids are difficult to assay because unsaturated acids are easily oxidised in air. Further- N more, lipolysis raises free fatty acid values, and this is obviously more important in patients with excess he- 0 patic triglyceride; and we have found that this may $\mathrm{\omega}$ occur in liver biopsy specimens taken at least 12 hours after death (SR Cairns, unpublished observation). The increased hepatic free fatty acid value found in $\mathbb{D}$ our patient is, however, unlikely to have resulted from + lipolysis as the biopsy specimen was taken immedi- $\frac{T}{T}$ ately after death. Use of internal standards during the $\stackrel{\vec{D}}{\stackrel{\circ}{D}}$ lipid extraction and assay also indicate that pronounced lipolysis had not occurred during the pro- $\stackrel{\mathbb{Q}}{\Omega}$ cedure. The addition of an antioxidant to the lipid 
extract minimises lipid peroxidation during analysis.

The finding of raised hepatic free fatty acids in this patient, who died with a severely fatty and inflamed liver after surgery for morbid obesity, lends further support to the suggestion that these acids are important in the pathogenesis of liver damage in this, and perhaps other, liver disorders accompanied by gross excess of lipid. Further studies are thus required to investigate lipid metabolism in various liver disorders, and recently developed methods, which analyse the subcellular localisation of lipid, ${ }^{10}$ would clearly be useful in this context. If patients with fatty liver associated with high tissue free fatty acid values can be identified in life - that is, before surgery for morbid obesity or in acute fatty liver of pregnancysuccessful treatment could possibly be given.

The mechanism of increased tissue free fatty acid values is uncertain. Lysosomes contain potent lipases, and disruption of these organelles would release high activities of lipases and other degradable enzymes into the hepatocyte cytoplasm. As free fatty acids are themselves lytic to lysosomal membranes ${ }^{6}{ }^{11}$ this may perpetuate the lipolysis. Lipolysis is also activated by adrenergic receptor mediated activation of lipases ${ }^{12}$ and the peroperative and postoperative stress that the patient experienced may have contributed to this effect. The increased cell free fatty acid content would have damaging effects on many intracellular organelles, particularly mitochondria, ${ }^{13-15}$ and this may be the critical factor in the pathogenesis of the organ failure.

We are grateful to Professor G Slavin for performing the immediate post mortem examination, Mrs $\mathbf{S}$ Kingsley for secretarial help, and the Medical Research Council (SRC) for a training fellowship.

\section{References}

${ }^{1}$ Cairns SR, Peters TJ. Micro methods for quantitative lipid analysis of human liver needle biopsy specimens. Clin Chim Acta 1983;127:373-82.

${ }^{2}$ Lowry OH, Rosebrough NJ, Farr AL, Randall RJ. Protein measurement with folin-phenol reagent. J Biol Chem 1951;193:265-75.

${ }^{3}$ Kapuschinski J, Skoczylas B. Simple and rapid fluorimetric method for DNA assay. Anal Biochem 1977;83:252-7.

${ }^{4}$ Cairns SR, Peters TJ. Biochemical analysis of hepatic lipid in alcoholic and diabetic and control subjects. Clin Sci 1983;65:645-52.

${ }^{5}$ Constantinides P. Endothelial injury in the pathogenesis of arteriosclerosis. Adv Exp Med Biol 1971;16A:185-212.

${ }^{6}$ Acosta D, Wenzel DG. Injury produced by free fatty acids to lysosomes and mitochondria in cultured heart muscle and endothelial cells. Atherosclerosis 1974;20:417-26.

${ }^{7}$ Wenzel DG, Hale TW. Toxicity of free fatty acids for cultured rat heart muscle and endothelial cells. Toxicology 1978;11:109-17.

${ }^{8}$ Eisele JW, Barker EA, Smuckler EA. Lipid content in the liver of fatty metamorphosis of pregnancy. Am J Pathol 1975;81:545-60.

${ }^{9}$ Maurelis PG, Ammon HV, Gleystein JJ, Komorowski RA, Charaf UK. Hepatic free fatty acids in alcoholic liver disease and morbid obesity. Hepatology 1983;3:226-31.

${ }^{10}$ Cairns SR, Peters TJ. Isolation of micro- and micro-droplet fractions from needle biopsy specimens of human liver and determination of the subcellular distribution of the accumulating liver lipids in alcoholic fatty liver. Clin Sci 1984;67:337-45.

${ }^{11}$ DeDuve C, Wattiaux R. Functions of lysosomes. Annual Review of Physiology 1966;28:435-92.

${ }^{12}$ Stiles GL, Caron MG, Lefkowitz RJ. $\beta$ Adrenergic receptors: biochemical mechanisms of physiological regulation. Physiol Rev 1984;64:661-743.

${ }^{13}$ Mellors A, Tappell AL, Savant PL, Desair ID. Mitochondrial swelling and uncoupling of oxidative phosphorylation by lysosomes. Biochim Biophys Acta 1967;143:299-309.

${ }^{14}$ Mela L, Olofsson K, Miller LD, Bacalzo LV, White RR. Effect of lysosomes and hypoxia on mitochondria in shock. Surg Forum 1971;22:19-21.

${ }^{15}$ Rubio V, Grisolia S. Prominent role of lysosomes in the proteolysis of rat liver mitochondria at neutral pH. Febs Let 1977;75:281-4.

Requests for reprints to: Professor TJ Peters, Division of Clinical Cell Biology, Clinical Research Centre, Watford Road, Harrow, Middlesex HA1 3UJ. 